\title{
Effects of steroidal estrogens on coral growth and reproduction
}

\author{
A. M. Tarrant ${ }^{1,4, *}$, M. J. Atkinson ${ }^{2}$, S. Atkinson ${ }^{3}$ \\ ${ }^{1}$ Department of Oceanography, University of Hawaii at Manoa, 1000 Pope Road, Honolulu, Hawaii 96822, USA \\ ${ }^{2}$ Hawaii Institute of Marine Biology, University of Hawaii at Manoa, PO Box 1346, Kaneohe, Hawaii 96743, USA \\ ${ }^{3}$ Alaska SeaLife Center, University of Alaska Fairbanks, PO Box 1329, Seward, Alaska 99664, USA \\ ${ }^{4}$ Present address: Woods Hole Oceanographic Institution, Biology Department, MS-32, Woods Hole, \\ Massachusetts 02543, USA
}

\begin{abstract}
Steroidal estrogens are well-described vertebrate hormones that also occur in invertebrates, where they have diverse biological effects. Estradiol-17 $\beta$ is contained in coral tissues and released into the surrounding water during multi-species coral mass-spawning events. Estrogens are also widely distributed environmental pollutants in coastal waters; thus corals and other reef invertebrates are exposed to a variety of estrogens and estrogen-like compounds with unknown organismal and ecological effects. Until now, there has been no experimental evidence to suggest that estrogens are biologically active in corals. We describe the effects of exogenous estradiol on the size and number of gametes spawned by coral colonies and the effects of estrone on coral growth rates and tissue thickness. Montipora capitata coral colonies treated with estradiol for 3 wk prior to spawning released fewer egg-sperm bundles than controls (29\% decrease). Porites compressa coral fragments ('nubbins') exposed continuously to estrone for 2 to $8 \mathrm{wk}$ had lower (13 to $24 \%$ ) skeletal growth rates than controls. Large coral nubbins that were treated with estrone had thicker tissue. While the mechanism for estrogen action for corals remains unknown, these experiments represent the first account of biological activity of steroidal estrogens in coral.
\end{abstract}

KEY WORDS: Estrogen $\cdot$ Coral $\cdot$ Reproduction $\cdot$ Endocrine disruption $\cdot$ Reef $\cdot$ Calcification

\section{INTRODUCTION}

Steroidal estrogens are well-described vertebrate hormones that also occur in echinoderms (Voogt \& Dieleman 1984, Hines et al. 1992), crustaceans (Van Beek \& De Loof 1988), mollusks (Lupo di Prisco \& Dessi'Fulgheri 1975, Reis-Henriques et al. 1990), and cnidarians (Slattery et al. 1997, Tarrant et al. 1999, Pernet \& Anctil 2002). Estrogen action in invertebrates is not understood, and diverse effects of exogenous estrogens on invertebrates have been reported, including stimulated ovarian and/or oocyte development (Shoenmakers et al. 1981, Sarojini et al. 1986, Wasson et al. 2000), blocked embryonic development (Hathaway \& Black 1969), altered enzymatic activities (Ghosh \& Ray 1993a,b), accumulation of proteins
(Ghosh \& Ray 1992, Wiens et al. 1999, Billinghurst et al. 2000), and cellular damage or even apoptosis (Wiens et al. 1999, Viarengo et al. 2000). On the other hand, some studies have failed to detect effects of exogenous estrogens on invertebrates (Hutchinson et al. 1999, Breitholtz \& Bengtsson 2001, Pascoe et al. 2002).

Aquatic pollutants, including pesticides, plasticizers, and detergent metabolites can disrupt endocrine function in vertebrates and invertebrates (Voogt et al. 1987, Monod et al. 1993, Purdom et al. 1994, Harries et al. 1997, Shurin \& Dodson 1997, Routledge et al. 1998, Zou \& Fingerman 1999, Billinghurst et al. 2000). Endocrine disruption occurs through several mechanisms, including mimicking or blocking action of endogenous hormones, particularly estrogens (Katzenellenbogen 1995, McLachlan 2001). Estrogenic contaminants (i.e. 
4-nonylphenol, a detergent metabolite and bisphenol A, a plasticizer) are widespread in streams in the United States (Kolpin et al. 2002); corresponding studies have not yet been conducted in coastal marine environments. Steroidal estrogens are also widely distributed in marine and freshwater environments, particularly in association with known sources of sewage (Kolpin et al. 2002, Atkinson et al. 2003).

Coral reefs and coral communities often occur in close proximity to human population centers, and reef organisms may be exposed to an array of chemical pollutants. Scleractinian corals are essential structural and ecological components of tropical coral reef ecosystems; disruption of coral physiological processes, such as growth and reproduction, would ultimately damage reef ecosystems. Scleractinian hard corals and alcyonacean soft corals contain steroidal estrogens, and estradiol is released during coral spawning events (Atkinson \& Atkinson 1992, Slattery et al. 1999, Tarrant et al. 1999). While corals can take up estrogens and other lipophilic contaminants from the water column, the role of estrogens, if any, in coral physiology has not been elucidated (Tarrant et al. 2001).

Our overall working hypotheses are: (1) estrogens and other steroids regulate reproduction and development in reef-building corals, (2) physiological processes in corals and other invertebrates are vulnerable to disruption by environmental estrogens or estrogen mimics, and (3) disruption of coral physiology by estrogenic chemicals can directly and indirectly disrupt reef ecosystem function. Until this study, there has been no experimental evidence that estrogens are biologically active in corals or other cnidarians. Thus, in this study we test, in 2 dominant species of corals, whether (1) estrogens alter basic reproductive parameters such as size and number of gametes, and (2) estrogens affect growth parameters, such as skeletal growth and tissue thickness.

\section{MATERIALS AND METHODS}

Overview. Three experiments were conducted to test the effects of (1) estradiol on coral spawning, (2) dilute estrone on coral growth during October (fall), and (3) dilute estrone on coral growth during March and April (spring). These 3 experiments are explained in greater detail below in separate sections. The purpose of these experiments was to provide an insight both into the physiological role of estrogens in corals and the potential for disruption of physiological processes by environmental sources of estrogens. Estrone concentrations in Kaneohe Bay range from below $0.04 \mathrm{ng} \mathrm{l}^{-1}$ (the detection limit) to $0.6 \mathrm{ng} \mathrm{l}^{-1}$ $(2.2 \mathrm{pM})$; concentrations greater than $1 \mathrm{ng} \mathrm{l}^{-1}$ (3.7 $\left.\mathrm{pM}\right)$ have been reported in coastal seawater with known sewage inputs (Atkinson et al. 2003).

In the spawning experiment, Montipora capitata coral colonies were exposed to high concentrations of estradiol prior to spawning in an attempt to load the tissue with estradiol. Estradiol was used in this experiment because it is the predominant biologically active form of estrogen in vertebrates, and is hypothesized to act as an endogenous hormone in corals.

In the fall and spring growth experiments, Porites compressa coral fragments were continuously exposed to $2 \mathrm{ng} \mathrm{l}^{-1}$ estrone, which is comparable to estrogen concentrations measured in coastal water near urban areas. Estrone was used in the growth experiments because it is has been detected in coastal marine habitats, particularly in areas with known sewage input (Atkinson et al. 2003).

Spawning experiment. Montipora capitata, formerly identified as $M$. verrucosa (Maragos 1977, 1995), is a common zooxanthellate coral on Hawaiian reefs. $M$. capitata is hermaphroditic and releases buoyant bundles of eggs and sperm in June, July and sometimes August, generally 1 to $4 \mathrm{~d}$ after the new moon (Hunter 1988). M. capitata coral colonies were collected from 3 patch reefs in Kaneohe Bay, Oahu, Hawaii: (1) the windward side of Coconut Island = Coconut Reef, (2) a patch reef in Central Kaneohe Bay = Checker Reef, and (3) a patch reef along the Sampam Channel = Sampam Reef. The 3 patch reefs were within $500 \mathrm{~m}$ of one another. Fertile colonies (having eggs visible under a dissecting microscope) were selected during May 2000.

A pilot study had indicated that the number of bundles spawned was correlated with colony volume, and that the predominant month of spawning varied with site of collection. To account for this variability, 32 colonies were separated into 16 pairs of colonies, such that the 2 colonies in each pair were collected from the same site and were of similar volume (mean $=$ $1480 \mathrm{~cm}^{3} \pm 102 \mathrm{SE}$ ) One member of each pair was randomly assigned to an estradiol treatment and the other to a control. Each colony was assigned to 1 of 6 outdoor tanks: 3 tanks for estradiol treatment and 3 for controls. Thus there were 5 to 6 colonies per tank, with a total coral volume of $7870 \mathrm{~cm}^{3} \pm 53 \mathrm{SE}$. Tanks were square with sides $1.2 \mathrm{~m}$, water depth 0.25 to $0.32 \mathrm{~m}$, and seawater volume was 410 l. Seawater flowed through tanks with a residence time of $60 \mathrm{~min}$.

In this study, colonies were paired because we expected that variability due to colony size and collection site would be greater than tank effects. This paired statistical design requires the assumption that colonies are independent units. Pseudoreplication occurs when the organisms within a treatment are not fully independent; for example, this can occur when organisms 
of a single treatment interact to affect the parameter of interest. One method of preventing pseudoreplication is to place organisms in separate containers. In fact, we have routinely found that such a design creates large variability in the treatment parameter as well as other chemical changes. Another way of reducing the effects of pseudoreplication is to design a system where interaction of the individuals is minimal, or impossible. Based on our knowledge of the maximum release and uptake kinetics of hormones (Tarrant et al. 2001, Atkinson \& Falter 2003), we designed experimental tanks to minimize interactions among colonies. The tanks had relatively low biomass (corals are spaced a colony or 2 apart) and high water turnover. In this study, as previously stated, we used 3 treatment tanks and 3 control tanks, with 5 to 6 colonies per tank, and high water turnover. We did not observe any significant differences between tanks within a treatment for any of the reproductive parameters measured.

Estradiol $(0.8 \mathrm{mg}$ dissolved in $10 \mathrm{ml}$ ethanol and mixed into $500 \mathrm{ml}$ seawater) was added to each treatment tank; ethanol in seawater was used as a control. Estradiol is considered to be insoluble in seawater and has only low solubility in ethanol; however, small amounts of estrogens can be added to seawater and remain in the water column for several days (Tarrant et al. 2001). In this experiment, 9 doses of estradiol were administered on alternate days to give a calculated starting concentration of $2300 \mathrm{ng} \mathrm{l}^{-1}$ (8.4 nM) estradiol in treatment tanks. The calculated concentration of ethanol in all tanks was $25 \mathrm{ml} \mathrm{l}^{-1}(20 \mathrm{mM})$. The last dose was given on the day of the June new moon (when spawning generally occurs). These dates were selected to coincide with the time of rapid increase in egg diameter in Montipora capitata (Hunter 1988). As each dose was added, water flow was stopped for $3 \mathrm{~h}$ to allow corals to take up the estradiol (Tarrant et al. 2001).

To quantify estradiol uptake, water samples (1 l) were collected at the beginning and end of the first and last dosing period for each tank. Samples were concentrated on Sep-Pak $\mathrm{C}_{18}$ columns and eluted with diethyl ether (Tarrant et al. 2001, Atkinson et al. 2003). Extracts were dried under nitrogen, and estradiol was quantified using radioimmunoassay (Atkinson \& Atkinson 1992).

Observers monitored spawning following 3 successive new moons in 2000 (June 2, July 1 and 30). Observations began 1 night before new moon and continued nightly for 3 to 5 nights until only trivial amounts of spawning were observed. Colonies were isolated in plastic containers prior to spawning. Positively buoyant egg-sperm bundles were collected using aspirators and poured into graduated cylinders. Volume measurements were converted to numbers of bundles using a linear relationship previously derived for this species (S. Kolinski unpubl.). Bundles (8 to 10) from each of 24 colonies were placed in water droplets and allowed to break apart. Egg diameter was measured along the longest axis and perpendicular to that axis using a dissecting microscope with a micrometer. Egg dimensions were used to calculate the projected area, assuming an oval shape. The number of eggs per bundle was recorded for 8 to 10 bundles from each of 23 colonies.

Fall growth experiment. Fragments from Porites compressa colonies were dissected in June 2000 and female colonies were identified (having eggs visible under a dissecting microscope). Some colonies lacked visible gametes; obvious male gametes were not seen. During September 2000, 1 to $3 \mathrm{~cm}$ branch tips (nubbins) were collected from these colonies by a snorkeller. Bottoms of the nubbins were smoothed using a belt sander, and nubbins were attached to plexiglass tiles with SuperGlue ${ }^{\mathrm{TM}}$ gel.

Six 201 aquaria were divided into 2 groups of 3 aquaria: estrone $\left(\mathrm{E}_{1}\right)$-treated, and control. A stocksolution of $400 \mathrm{ng} \mathrm{l}^{-1} \mathrm{E}_{1}(1.5 \mathrm{nM})$ in freshwater was contained in a $70 \mathrm{l}$ cooler. A second cooler contained freshwater only. Solutions from the 2 coolers ran through plastic tubing and dripped into the 6 aquaria at $10 \mathrm{ml}$ $\min ^{-1}$. For the estrone treatment this drip rate gave a concentration of $2 \mathrm{ng} \mathrm{l}^{-1}$ (7.4 pM) in the aquaria. Seawater flowed into each aquarium at $21 \mathrm{~min}^{-1}$, mixing with the estrone or control solution, and producing a water turnover time of only $10 \mathrm{~min}$. Fifteen coral nubbins were randomly assigned to each of six $20 \mathrm{l}$ aquaria. Tanks were cleaned on alternate days. Estrone and control solutions were replenished daily. Seawater flow rates and drip rates of the steroid solution were also adjusted daily. Coral skeletal weight was determined at the beginning of the experiment and 12 to $18 \mathrm{~d}$ later by buoyant weighing of nubbins $\left(W_{\text {air }}=W_{\text {water }} /\left[1-\left(D_{\text {wa- }}\right.\right.\right.$ ter $\left.\left./ D_{\text {coral }}\right)\right]$, where $W$ is weight and $D$ density; Jokiel et al. 1978). Because coral tissue comprises only a small portion of the total nubbin weight, and is close to the density of seawater, subtle changes in tissue thickness do not have a large effect on density or buoyant weight (Davies 1989). After 1 mo, nubbins were split longitudinally with bone shears, and tissue thickness was measured with calipers at the growing tip of the nubbin. Nubbins from each tank were then combined; dry weight and volume (by water displacement) were determined and used to calculate skeletal density. Density measurements were used to convert buoyant weight into skeletal weight (Jokiel et al. 1978). Density measurements for coral nubbins ranged from 1.56 to $1.74 \mathrm{~g} \mathrm{ml}^{-1}$ and did not vary significantly with experiment or treatment. A mean density of $1.65 \mathrm{~g} \mathrm{~m}^{-1}$ was used in all calculations.

Spring growth experiment. The spring growth experiment was conducted over $8 \mathrm{wk}$ (March to April 2001), and was identical to the previous experiment, except as noted. As in the fall experiments, Porites 
compressa nubbins were exposed to $2 \mathrm{ng} \mathrm{l}^{-1}$ estrone (7.4 pM) or to a control solution (ethanol carrier only). Nubbins were weighed every $2 \mathrm{wk}$, giving a total of 5 weight measurements for each nubbin. A third-order polynomial was used to fit the growth rate, and the fitted initial and final weights were used to calculate the overall growth rate for each nubbin over $8 \mathrm{wk}$.

Five nubbins were randomly selected from each aquarium, and separately homogenized using a mortar and pestle. The protein concentration in the resulting slurry was measured by the bicinchroninic acid method (Pierce Kit, Tarrant et al. 1999).

\section{RESULTS}

\section{Spawning experiment}

The concentration of estradiol $\left(\mathrm{E}_{2}\right)$ measured in treatment tanks 15 min after the addition of exogenous $E_{2}$ ranged from 18 to $>100 \mathrm{ng} \mathrm{l}^{-1}$ (Table 1 ), less than $2 \%$ of the calculated value of $2300 \mathrm{ng} \mathrm{l}^{-1}(8.4 \mathrm{nM})$. Table 1 shows that treated tanks were subjected to approximately 10 -fold enrichment in $\mathrm{E}_{2}$ relative to controls, and that most of the added $E_{2}$ was taken up during incubations. Mean uptake in treated tanks $\left\{\left(\left[\mathrm{E}_{2}\right]_{\text {initial }}-\right.\right.$ $\left.\left.\left[\mathrm{E}_{2}\right]_{\text {final }}\right)(383 \mathrm{l})(9 \mathrm{~d})\right\}$ was $278 \mu \mathrm{g}(1.02 \mu \mathrm{mol})$. Based on the volume of coral per tank, coral skeletal density, and reported concentrations of $\mathrm{E}_{2}$ in Montipora capitata tissue (Tarrant 1998), we estimate roughly $7 \mu \mathrm{g}$ of $E_{2}$ tank $^{-1}$ was contained in the coral tissue prior to the
Table 1. Montipora capitata. Uptake of estradiol during spawning experiment. Starting concentrations were determined from water sampled 15 min after addition of exogenous estrogen; ending concentrations were from water sampled $3 \mathrm{~h}$ later. < and > represent values outside of the assay working range for the volumes analyzed. Concentrations are duplicate measurements from a water sample; where both measurements fall outside the working range of the assay, only a single number is given

\begin{tabular}{|rllll|}
\hline \multirow{2}{*}{ Day } & Tank & Treatment & \multicolumn{3}{c|}{$\begin{array}{c}\text { Concentration }\left(\mathrm{ng} \mathrm{l}^{-1} \text { ) }\right. \\
\text { Start }\end{array}$} & \multicolumn{1}{c|}{ End } \\
\hline 1 & & & & \\
& & Estradiol & 30,30 & 2,3 \\
1 & 3 & Estradiol & 30,20 & $>10,7$ \\
1 & 4 & Estradiol & $>100$ & $>10,2$ \\
21 & 2 & Estradiol & 40,30 & 1,3 \\
21 & 3 & Estradiol & 30,30 & $>10,5$ \\
21 & 4 & Estradiol & 30,30 & $>10$ \\
1 & 1 & Control & $<2$ & Not assayed \\
1 & 5 & Control & $4,<2$ & Not assayed \\
1 & 6 & Control & $<2$ & Not assayed \\
21 & 1 & Control & $<2$ & Not assayed \\
21 & 5 & Control & $<2,2$ & $<0.5$ \\
21 & 6 & Control & $<2$ & $<0.5$ \\
& & & & \\
\hline
\end{tabular}

experiment. Thus, over the course of the experiment, coral colonies received approximately 40-fold enrichment in $\mathrm{E}_{2}(278 / 7 \approx 40)$.

Estradiol did not affect egg surface area (control = $0.50 \mathrm{~mm}^{2}$, treatment $=0.51 \mathrm{~mm}^{2}, \mathrm{df}=21, t=-0.35, \mathrm{p}=$ 0.73 ) nor the number of eggs per bundle (control = 13.5, treatment $=13.9, \mathrm{df}=20, t=-0.35, \mathrm{p}=0.73$ ). Treated colonies released a mean of 4860 fewer bun-
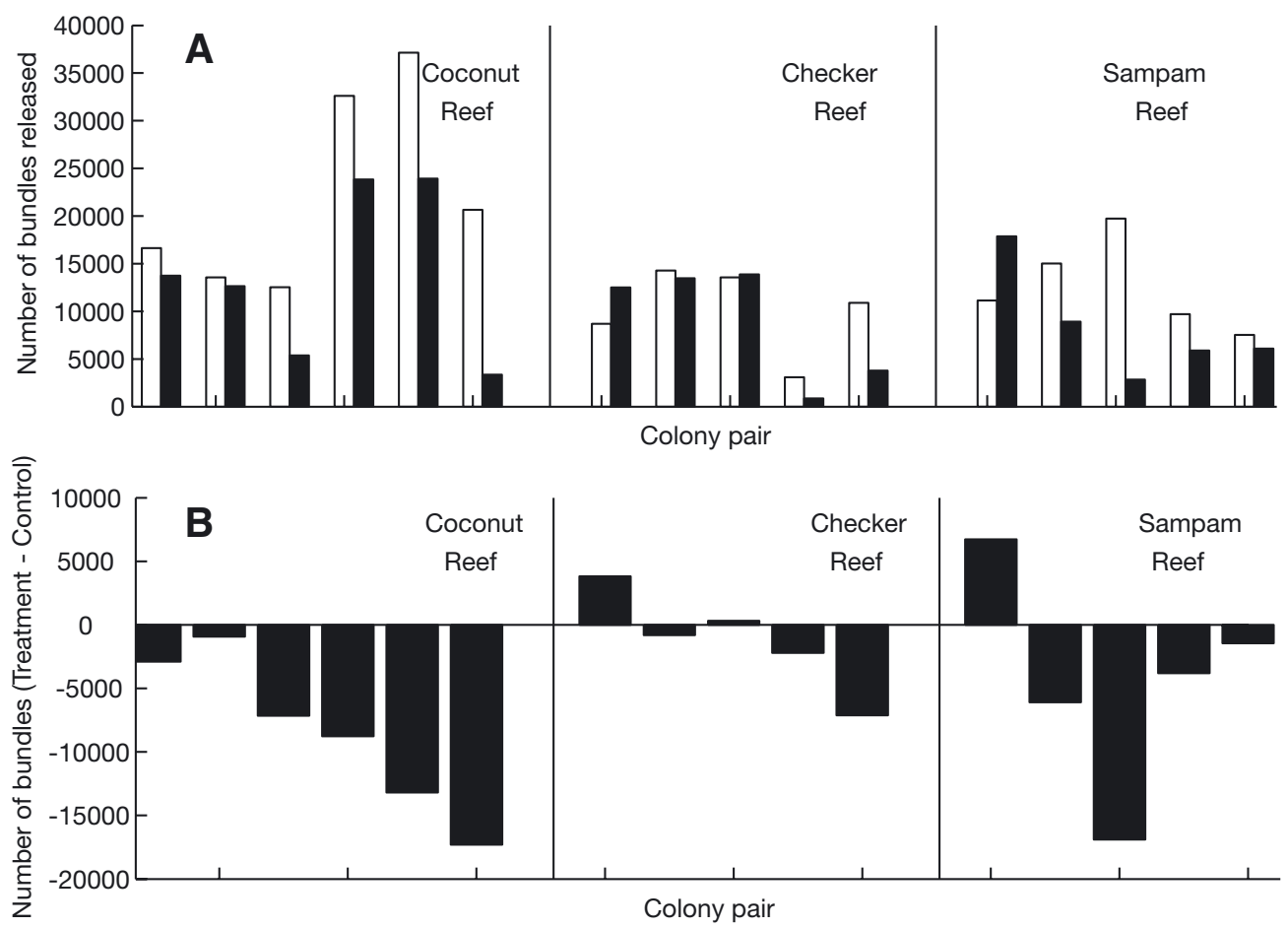

Fig. 1. Montipora capitata. Number of egg-sperm bundles spawned in response to estradiol treatment. (A) Total number of bundles spawned by estradiol-treated (black bars) and control (open bars) colonies during June and July, grouped by collection site and pair. (B) Difference between treated and control colonies for each pair, grouped by collection site 
dles per colony than the corresponding control colony, a reduction of nearly one-third (paired $t$-test, $\mathrm{df}=15$, $t=2.87, \mathrm{p}=0.012$, Fig. 1). Coconut Reef showed the largest effect of estradiol treatment, and Checker Reef showed the smallest effect.

\section{Fall growth experiment}

Mean weights of nubbins were $1.43 \mathrm{~g} \pm 0.07 \mathrm{SE}$ at the start of the experiment and $1.67 \mathrm{~g} \pm 0.08 \mathrm{SE}$ after 12 to $18 \mathrm{~d}$, giving a mean growth rate for the 2 groups of $14.8 \mathrm{mg} \mathrm{d}^{-1} \pm 0.9 \mathrm{SE}$ (Fig. 2A). Growth rate was positively correlated with initial weight $\left(\mathrm{mg} \mathrm{d}^{-1}=0.0099\right.$ $\left.[\mathrm{mg}]+0.721, \mathrm{R}^{2}=0.61, \mathrm{p}<0.001\right)$. Initial weight was not significantly different among treatments (1-way ANOVA, $F=0.37, \mathrm{p}=0.54)$. Growth rate in the estrone treatment was $24 \%$ lower than the control growth rate (Fig. 2B, Table 2, ANCOVA with initial weight as a covariate, $\mathrm{p}=0.0024$ ).

\section{Spring growth experiment}

In the spring experiment, mean weights of nubbins were $1.36 \mathrm{~g} \pm 0.04 \mathrm{SE}$ at the start of the experiment and $2.09 \mathrm{~g} \pm 0.06 \mathrm{SE}$ after $8 \mathrm{wk}$, giving a mean growth rate of $13.0 \mathrm{mg} \mathrm{d}^{-1} \pm 0.5 \mathrm{SE}$ (Fig. 2B).

Although initial weights did not differ among treatments (1-way ANOVA, $F<0.01, \mathrm{p}=0.97$ ), growth rate was significantly correlated with initial weight $\left(\mathrm{mg} \mathrm{d}^{-1}=\right.$ $\left.0.0054[\mathrm{mg}]+5.75, \mathrm{R}^{2}=0.20, \mathrm{p}<0.001\right)$. Growth rate of nubbins in the estrone treatment was $13 \%$ lower than the control growth rates; this effect was significant at $\alpha=$ 0.1 (Table 2, ANCOVA with initial weight as a covariate, $\mathrm{p}=0.081$ ). When the spring and fall experiments are considered together, specific growth rate (growth rate divided by initial weight) decreased significantly in response to estrone (Table 3, 2-way ANOVA, p = 0.0003)

Tissue thickness at the tip of the branches was also positively correlated with weight. Because the relationship was nonlinear, analysis of covariance was not appropriate. Among the smaller $50 \%$ of the fragments, there was no effect of treatment on tip tissue thickness, but among the larger $50 \%$ of the fragments, estrone was associated with thicker tissue (Table 4). Treatment with estrone had no significant effect on the amount of protein present (1-way ANOVA, $\mathrm{p}=0.40$ ).

\section{DISCUSSION}

In the spawning experiment, exposure to estradiol reduced the number of bundles spawned by Montipora capitata colonies by $29 \%$ relative to control colonies.
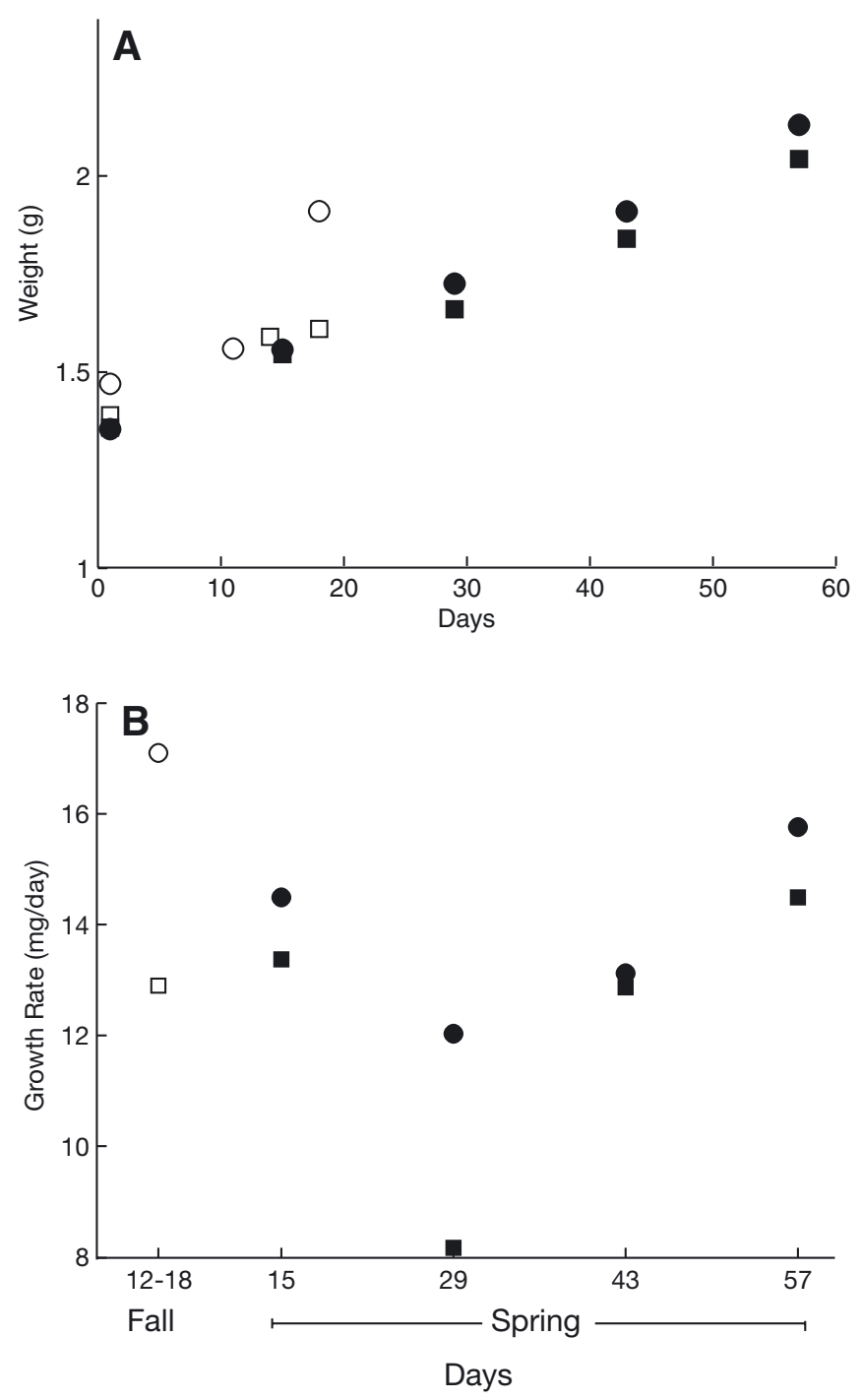

Fig. 2. Porites compressa. (A) Mean skeletal weight of nubbins versus time for fall $(\mathrm{O}=$ control, $\square=$ estrone $)$ and spring $(\boldsymbol{O}=$ control, $\boldsymbol{\square}=$ estrone) experiments. Nubbins were weighed twice in the fall experiment at the start of the experiment, and 12 to $18 \mathrm{~d}$ later (not all nubbins were weighed on the same day). In the spring experiment, all nubbins were weighed on the same day at 2 wk intervals. (B) Mean growth rates (change in weight divided by time) of nubbins for fall and spring experiments. Symbols as per (A). In the spring experiment, growth rates are displayed for each 2 wk interval of the 8 wk experiment

This result supports our hypothesis that estrogens are natural bioregulators in corals, and suggests that exogenous or environmental estrogens have the potential to reduce fecundity in corals. Stressors, such as injury, disease, and bleaching, can also reduce the number of gametes spawned (Szmant \& Gassman 1990, Van Veghel \& Bak 1994, Ward 1995, Rinkevich 1996), but additional experiments will be needed to assess the cumulative or synergistic effects of multiple 
stressors, including estrogenic compounds, in the environment. The spawning experiment in the present study tested the reproductive response of corals to estradiol under specific experimental conditions; these

Table 2. Porites compressa. Growth rate of corals by treatment in 2 experiments. ANCOVA of treatment effect on coral growth rate for fall and spring experiments using initial weight as a covariate

\begin{tabular}{|c|c|c|c|c|}
\hline \multirow[t]{2}{*}{ Treatment } & \multicolumn{4}{|c|}{$\begin{array}{c}\text { Growth rate }\left(\mathrm{mg} \mathrm{d}^{-1}\right) \\
\text { Mean } \pm \mathrm{SE}\end{array}$} \\
\hline & \multicolumn{2}{|c|}{ Fall } & \multicolumn{2}{|c|}{ Spring } \\
\hline Control & \multicolumn{2}{|c|}{$17.1 \pm 1.19$} & \multicolumn{2}{|c|}{$13.8 \pm 0.68$} \\
\hline Estrone & \multicolumn{2}{|c|}{$12.9 \pm 1.20$} & \multicolumn{2}{|c|}{$12.2 \pm 0.79$} \\
\hline Effect & df & MS & $F$ & $\mathrm{p}$ \\
\hline \multicolumn{5}{|l|}{ Fall experiment } \\
\hline Dose & 1 & 200 & 9.96 & 0.0024 \\
\hline Weight (covariate) & 1 & 2450 & 122 & $<0.001$ \\
\hline Dose $\times$ Weight & 1 & 3.41 & 0.17 & 0.682 \\
\hline Error & 70 & 20.1 & & \\
\hline \multicolumn{5}{|l|}{ Spring experiment } \\
\hline Dose & 1 & 61.8 & 3.11 & 0.081 \\
\hline Weight (covariate) & 1 & 458 & 23.0 & $<0.001$ \\
\hline Dose $\times$ Weight & 1 & 1.84 & 0.09 & 0.76 \\
\hline Error & 133 & 19.9 & & \\
\hline
\end{tabular}

Table 3. Porites compressa. Specific growth rate (growth rate divided by initial weight) for steroid treatments and 2-way ANOVA of effects of estrone on specific growth rate

\begin{tabular}{|c|c|c|c|c|}
\hline \multirow[t]{2}{*}{ Treatment } & \multicolumn{4}{|c|}{$\begin{array}{c}\text { Specific growth rate }\left(\mathrm{mg} \mathrm{g}^{-1} \mathrm{~d}^{-1}\right) \\
\text { Mean } \pm \text { SE }\end{array}$} \\
\hline & \multicolumn{2}{|c|}{ Fall } & \multicolumn{2}{|c|}{ Spring } \\
\hline Control & \multirow{2}{*}{\multicolumn{2}{|c|}{$\begin{aligned} 11.9 & \pm 0.61 \\
9.2 & \pm 0.57\end{aligned}$}} & \multicolumn{2}{|c|}{$10.7 \pm 0.50$} \\
\hline Estrone & & & & \pm 0.57 \\
\hline Effect & df & MS & $F$ & $\mathrm{p}$ \\
\hline Experiment & 1 & 12.8 & 0.989 & 0.322 \\
\hline Treatment & 1 & 180 & 13.9 & 0.0003 \\
\hline $\begin{array}{l}\text { Interaction } \\
\text { (Experimen }\end{array}$ & $\begin{array}{c}1 \\
\text { ment) }\end{array}$ & 15.7 & 1.22 & 0.272 \\
\hline Error & 161 & 12.9 & & \\
\hline
\end{tabular}

Table 4. Porites compressa. Effects of estrone on tissue thickness at tips of coral nubbins during growth experiments. Treatment means for spring and fall experiments. In the spring experiment, the mean for each treatment is reported along with treatment means for the larger and smaller $50 \%$ of the nubbins

\begin{tabular}{lcccc|}
\multirow{2}{*}{ Treatment } & \multirow{4}{*}{ Tissue thickness at tip (mm, mean \pm SE) } \\
& Fall & Spring (overall) & Spring (small) & Spring (large) \\
\hline Control & $2.80 \pm 0.130$ & $3.04 \pm 0.112$ & $2.86 \pm 0.183$ & $3.23 \pm 0.112$ \\
Estrone & $3.01 \pm 0.135$ & $3.14 \pm 0.120$ & $2.81 \pm 0.139$ & $3.65 \pm 0.154$ \\
\hline
\end{tabular}

results cannot be generalized to predict the response to estrogen doses administered at different times or in different concentrations.

Exposure to estradiol reduced the number of bundles spawned relative to controls in most colonies from all 3 sites. The effect was strongest at Coconut Reef, and 3 treated colonies from the other sites actually released more bundles than control colonies (Fig. 1). The number of eggs or larvae produced by a coral colony can vary greatly both among coral colonies and within a single colony between reproductive seasons (Sier \& Olive 1994); the degree to which genetic versus environmental factors affect fecundity in corals is unknown. In the present study, the apparent site-specific variation in response to treatment suggests that asynchronous gamete development among colonies, particularly colonies collected from different sites, contributes to the variable responses to estrogen treatment. Gametogenesis is 'loosely synchronous' in the coral Porites porites (Tomascik \& Sander 1987), and Montipora capitata exhibits 'a great deal of variability and flexibility in timing of spawning' (Hunter 1988). While the temporal variability in the timing of gamete development or spawning was not explicitly addressed in this study, the initial reproductive condition of the colonies may have varied among sites and created a variable response (Tarrant 2002). These data demonstrate the need to test the effects of estrogens on corals at different points in the reproductive cycle.

Mean skeletal growth rates of Porites compressa in all treatments were similar in the 2 growth experiments (15.4 and $13.7 \mathrm{mg} \mathrm{d}^{-1}$ in the fall and spring experiments, respectively), and estrone-treated corals consistently grew most slowly in both experiments (24\% slower than control in fall and 13\% slower than control in spring) and during each $2 \mathrm{wk}$ period of the spring experiment (Fig. 2B). In comparison, Marubini $\&$ Davies (1996) report that addition of $1 \mu \mathrm{M}$ nitrate to $P$. porites resulted in a $25 \%$ reduction in the skeletal growth rate after $40 \mathrm{~d}$, and $5 \mu \mathrm{M}$ nitrate caused a $50 \%$ reduction in the skeletal growth rate. Similarly, a reduction of $\mathrm{pH}$ from 8.0 to 7.2 resulted in a $50 \%$ reduction in skeletal growth rate (Marubini \& Atkinson 1999). Thus, the reduction in growth rate caused by exposure to dilute estrone $\left(2 \mathrm{ng} \mathrm{l}^{-1}\right.$, $7.4 \mathrm{pM}$ ) is comparable to that caused by 10- to 50-fold nutrient enrichment.

In the spring growth experiment, tissue was thicker in estrone-treated corals relative to control. The effect was only significant among the larger nubbins; we suggest that there is a threshold size for estrone effects. Patterns in growth rate and tissue thickness are consistent with the hypothesis 
that estrogens cause cellular proliferation in corals, perhaps at the expense of skeletal growth. Estrogens also regulate bone development and maintenance in mammals through an apparently complex mechanism involving differential roles of the estrogen receptor- $\alpha$ and $-\beta$ (Lindberg et al. 2001). Additional studies are needed to determine whether estrogens play a general role in mineralization of invertebrate skeletons.

The concentration of $E_{1}$ used in the growth experiments represented only a modest enhancement over ambient levels particularly when one considers that nearshore corals may be simultaneously exposed to a suite of estrogenic chemicals. $E_{1}$ concentration in Kaneohe Bay water is 0.04 to $0.6 \mathrm{ng} \mathrm{l}^{-1}$; thus an approximate input of $2 \mathrm{ng} \mathrm{l}^{-1}$ represents a 3 - to 50-fold enhancement.

The mode of action of estrogen in coral remains unknown. Although several nuclear receptors have been identified in corals, an estrogen receptor has not (Grasso et al. 2001, Tarrant 2002). Similarly, no thyroid hormone receptor has been identified in cnidarians, although iodinated organic compounds reportedly affect cnidarian strobilation and mineralization (Spangenberg 1984). Thus estrogens and other bioregulatory molecules may act through novel or primitive mechanisms in cnidarians. An understanding of these mechanisms would elucidate the evolution of hormone-receptor systems and perhaps contribute to the understanding of hormone action across the diversity of animals.

To fully explain the effects of estrogens on growth and reproduction, it will be necessary to test the effects of several forms of estrogen across a range of concentrations. For example, ethinyl estradiol, the predominant synthetic estrogen used in oral contraceptives, could also be used experimentally as it is more resistant to metabolic degradation and has been identified in sewage effluent (Desbrow et al. 1998). In the spawning experiment, concentrations of estradiol measured 15 min after dosing were much lower than calculated. Initial concentrations were also variable, so this material may have been patchy or formed a surface film. Based on our previous results (Tarrant et al. 2001, authors' unpubl. data) we do not expect that a large portion of the estradiol would have adsorbed to the sides of the tanks. In spite of this problem with solubility and mixing, we were able to load a large amount of estrogen into the coral tissue relative to predicted endogenous levels. In future experiments, it may be necessary to use a more soluble form of estrogen, such as cyclodextrin-encapsulated estradiol (Spencer \& Purdy 1995). A water-soluble estrogen complex could be used to describe the range of effects of estrogen (physiological and pharmacological), but would be less useful in predicting effects of environmental exposures to estrogenic compounds.
These experiments represent the first account of biological activity of steroidal estrogens in coral. Results from this study and previous findings in other invertebrates suggest that environmental effects of estrogens may extend well beyond the disruption of mammalian reproduction. While exposure to exogenous estrogen clearly affects coral growth and reproduction, the effects were not large. Further research is needed to determine dose-response relationships and sensitivity to different forms of estrogen. It also is not yet known how these estrogens are synthesized or stored by corals, or how estrogens accumulate in coral tissue and affect other organisms (i.e. predators and cryptic fauna associated with coral colonies). It is clear now that estrogens and estrogen-like compounds are prevalent in the environment, that corals can take up estrogens, and that estrogens can affect coral growth and reproduction.

Acknowledgements. We thank A. Baco-Taylor, M. Carmichael, F. Cox, J. Falter, J. Fleming, E. Hochberg, H. Hommy, S. Kolinski, F. Stanton, I. Stowe, C. Taylor, R. Tomasetti, and M. Weber for assistance in sampling. D. Krupp provided photographic equipment for quantifying egg size. Funding was provided by an EPA STAR fellowship to A.M.T. Additional funding was provided by the University of Hawaii Sea Grant College program, Institutional Grant No. NA86RG0041. The views expressed herein are those of the authors and do not necessarily reflect the views of NOAA or any of its subagencies.

\section{LITERATURE CITED}

Atkinson MJ, Falter JL (2003) Coral reefs. In: Black KD, Shimmield GB (eds) Biogeochemistry of marine systems. CRC Press, Bota Raton, FL, p 40-64

Atkinson S, Atkinson MJ (1992) Detection of estradiol-17 $\beta$ during a mass coral spawn. Coral Reefs 11:33-35

Atkinson S, Atkinson M, Tarrant A (2003) Estrogens from sewage in the coastal marine environment. Environ Health Perspect 111:531-5

Billinghurst Z, Clare A, Matsumura K, Depledge M (2000) Induction of cypris major protein in barnacle larvae by exposure to $4-n$-nonylphenol and $17 \beta$-oestradiol. Aquat Toxicol 47:203-212

Breitholtz M, Bengtsson BE (2001) Oestrogens have no hormonal effect on the development and reproduction of the harpacticoid copepod Nitocra spinipes. Mar Pollut Bull 42: 879-886

Davies P (1989) Short-term growth measurements of corals using an accurate buoyant weighing technique. Mar Biol 101:389-395

Desbrow C, Routledge EJ, Brighty GC, Sumpter JP, Waldock $M$ (1998) Identification of estrogenic chemicals in STW effluent. 1. Chemical fractionation and in vitro biological screening. Environ Sci Tech 32:1549-1558

Ghosh D, Ray AK (1992) Evidence for physiological responses to estrogen in freshwater prawn, Macrobrachium rosenbergii. J Inland Fish Soc India 24:15-21

Ghosh D, Ray AK (1993a) 17ß-hydroxysteroid dehydrogenase activity of ovary and hepatopancreas of freshwater prawn, Macrobrachium rosenbergii: relation to ovarian condition and estrogen treatment. Gen Comp Endocrinol 89: $248-254$ 
Ghosh D, Ray AK (1993b) Subcellular action of estradiol-17 $\beta$ in a freshwater prawn, Macrobrachium rosenbergii. Gen Comp Endocrinol 90:273-281

Grasso LC, Hayward DC, Trueman JWH, Hardie KM, Janssens PA, Ball EE (2001) The evolution of nuclear receptors: evidence from the coral Acropora. Mol Phylogen Evol 21:93-102

Harries JE, Sheahan DA, Jobling S, Matthiessen P, Neall P, Sumpter JP, Tylor T, Zaman N (1997) Estrogenic activity in five United Kingdom rivers detected by measurement of vitellogenins in caged male trout. Environ Toxicol Chem 16:534-542

Hathaway RR, Black RE (1969) Interconversions of estrogens and related developmental effects in sand dollar eggs. Gen Comp Endocrinol 12:1-11

Hines GA, Watts SA, Sower SA, Walker CW (1992) Sex steroid levels in the testes, ovaries, and pyloric caeca during gametogenesis in the sea star Asterias vulgaris. Gen Comp Endocrinol 87:451-460

Hunter CL (1988) Environmental cues controlling spawning in two Hawaiian corals, Montipora verrucosa and $M$. dilatata. Proc 6th Int Coral Reef Symp, Townsville, 2: 727-732

Hutchinson T, Pounds N, Hampel M, Williams T (1999) Impact of natural and synthetic steroids on the survival, development and reproduction of marine copepods (Tisbe battagliai). Sci Total Environ 233:167-179

Jokiel P, Maragos J, Franzisket L (1978) Coral growth: buoyant weight technique. Monogr Oceanogr Methodol 5: $529-542$

Katzenellenbogen JA (1995) The structural pervasiveness of estrogen activity. Environ Health Perspect 103(Suppl 7): 99-101

Kolpin D, Furlong E, Meyer M, Thurman E, Zaugg S, Barber L, Buxton H (2002) Pharmaceuticals, hormones and other organic wastewater contaminants in US streams, 1999-2000: a national reconnaissance. Environ Sci Tech 36:1202-1211

Lindberg M, ALatalo S, Halleen J, Mohan S, Gustafsson J, Ohlsson C (2001) Estrogen receptor specificity in the regulation of the skeleton in female mice. J Endocrinol 171: 229-236

Lupo di Prisco C, Dessi'Fulgheri F (1975) Alternative pathways of steroid biosynthesis in gonads and hepatopancreas of Aplysia depilans. Comp Biochem Physiol 50B:191-195

Maragos J (1977) Order Scleractinia: stony corals. In: Devaney DM, Eldredge LG (eds) Reef and shore fauna of Hawaii, Section 1: Protozoa through Ctenophora. Bishop Museum Press, Honolulu, p 158-241

Maragos J (1995) Revised checklist of extant shallow-water stony coral species from Hawaii (Cnidaria: Anthozoa: Scleractinia). Bishop Mus Occas Pap 42:54-55

Marubini F, Atkinson M (1999) Effects of lowered pH and elevated nitrate on coral calcification. Mar Ecol Prog Ser 188: $117-121$

Marubini F, Davies PS (1996) Nitrate increases zooxanthellae population density and reduces skeletogenesis in corals. Mar Biol 127:319-328

McLachlan J (2001) Environmental signaling: what embryos and evolution teach us about endocrine disrupting chemicals. Endocrin Rev 22:319-341

Monod G, Mones AD, Fostier A (1993) Inhibition of ovarian microsomal aromatase and follicular oestradiol secretion by imidazole fungicides in rainbow trout. Mar Environ Res 35:153-157

Pascoe D, Carroll K, Karntanut W, Watts M (2002) Toxicity of
$17 \alpha$-ethinylestradiol and bisphenol A to the freshwater cnidarian Hydra vulgaris. Arch Environ Contam Toxicol 43:56-63

Pernet V, Anctil M (2002) Annual variations and sex-related differences of estradiol-17 $\beta$ levels in the anthozoan Renilla koellikeri. Gen Comp Endocrinol 129:63-68

Purdom CE, Hardiman PA, Bye VJ, Eno NC, Tyler CR, Sumpter JP (1994) Estrogenic effects of effluent from sewage treatment works. Chem Ecol 8:275-285

Reis-Henriques MA, Le Guellec D, Remy-Martin JP, Adessi GL (1990) Studies of endogenous steroids from the marine mollusc Mytilus edulis L. by gas chromatography and mass spectroscopy. Comp Biochem Physiol 95B:303-309

Rinkevich B (1996) Do reproduction and regeneration in damaged corals compete for energy allocation? Mar Ecol Prog Ser 143:297-302

Routledge EJ, Sheahan D, Desbrow C, Brighty GC, Waldock M, Sumpter JP (1998) Identification of estrogenic chemicals in STW effluent. 2. In vivo responses in trout and roach. Environ Sci Tech 32:1559-1565

Sarojini R, Jayalakshmi K, Sambashivarao S (1986) Effect of external steroids on ovarian development in freshwater prawn, Macrobrachium lamerrii. J Adv Zool 7:50-53

Shoenmakers HJN, Bohemen CGV, Dieleman SJ (1981) Effects of oestradiol-17 $\beta$ on the ovaries of the starfish Asterias rubens. Dev Growth Diff 23:125-135

Shurin JB, Dodson SI (1997) Sublethal toxic effects of cyanobacteria and nonylphenol on environmental sex determination and development in Daphnia. Environ Toxicol Chem 16:1259-1267

Sier C, Olive P (1994) Reproduction and reproductive variability in the coral Pocillopora verrucosa from the Republic of Maldives. Mar Biol 118:713-722

Slattery M, Hines GA, Watts SA (1997) Steroid metabolism in Antarctic soft corals. Polar Biol 18:76-82

Slattery M, Hines GA, Starmer J, Paul VJ (1999) Chemical signals in gametogenesis, spawning, and larval settlement and defense of the soft coral Sinularia polydactyla. Coral Reefs 18:75-84

Spangenberg DB (1984) Effects of exogenous thyroxine on statolith synthesis and resorption in Aurelia. Am Zool 24: 917-923

Spencer B, Purdy W (1995) High-performance liquid chromatographic separation of equilin, estrone, and estrogen derivatives with cyclodextrins as mobile phase additives. J Liquid Chromatogr 18:4063-4080

Szmant A, Gassman N (1990) The effects of prolonged 'bleaching' on the tissue biomass and reproduction of the reef coral Montastrea annularis. Coral Reefs 8:217-224

Tarrant AM (1998) Meaurement of estradiol and estrone in tissue of the scleractinian coral Montipora verrucosa, analytical developments and indications of seasonality. MSc thesis, University of Hawaii at Manoa, Honolulu

Tarrant A (2002) Estrogen action in scleractinian corals: sources, metabolism and physiological effects. PhD thesis, University of Hawaii at Manoa, Honolulu

Tarrant AM, Atkinson S, Atkinson MJ (1999) Estrone and estradiol-17 $\beta$ concentration in tissue of the scleractinian coral, Montipora verrucosa. Comp Biochem Physiol 122A:85-92

Tarrant AM, Atkinson MJ, Atkinson S (2001) Uptake of estrone by a coral reef community. Mar Biol 139:321-325

Tomascik T, Sander F (1987) Effects of eutrophication on reefbuilding corals. III. Reproduction of the reef-building coral Porites porites. Mar Biol 94:77-94

Van Beek E, De Loof A (1988) Radioimmunological determinations of concentrations of six $\mathrm{C}_{21}, \mathrm{C}_{19}$, and $\mathrm{C}_{18}$ steroids 
during the reproductive cycle of female Artemia sp. (Crustacea: Anostraca). Comp Biochem Physiol 89A:595-599

Van Veghel M, Bak R (1994) Reproduction characteristics of the polymorphic Caribbean reef building coral Montastrea annularis. III. Reproduction in damaged and regenerating colonies. Mar Ecol Prog Ser 109:229-233

Viarengo A, Marro A, Marchi B, Burlando B (2000) Single and combined effects of heavy metals and hormones on lysosomes of haemolymph cells from the mussel Mytilus galloprovincialis. Mar Biol 137:907-912

Voogt PA, Dieleman SJ (1984) Progesterone and oestrone levels in the gonads and pyloric caeca of the male sea star Asterias rubens: a comparison with the corresponding levels in the female sea star. Comp Biochem Physiol 79A:635-639

Voogt PA, Den Besten PJ, Kusters GCM, Messing MWJ (1987) Effects of cadmium and zinc on steroid metabolism and steroid level in the sea star Asterias rubens L. Comp

Editorial responsibility: Charles Birkeland (Contributing Editor), Honolulu, Hawaii, USA
Biochem Physiol 86C:83-89

Ward S (1995) The effect of damage on the growth, reproduction and storage of lipids in the scleractinian coral Pocillopora damicornis (Linnaeus). J Exp Mar Biol Ecol 187: 193-206

Wasson KM, Gower BA, Watts SA (2000) Responses of ovaries and testes of Lytechinus variegatus (Echinodermata: Echinoidea) to dietary administration of estradiol, progesterone and testosterone. Mar Biol 137:245-255

Wiens M, Seack J, Koziol C, Hassanein HMA, Steffen R, Korzhev M, Schroder HC, Muller WEG (1999) 17 $\beta$-estradiol-dependent regulation of chaperone expression and telomerase activity in the marine sponge Geodia cydonium. Mar Biol 133:1-10

Zou E, Fingerman M (1999) Effects of estrogenic agents on chitobiase activity in the epidermis and hepatopancreas of the fiddler crab, Uca pugilator. Ecotoxicol Environ Safety 42:185-190

Submitted: January 3, 2003; Accepted: November 28, 2003 Proofs received from author(s): February 17, 2004 